\title{
MAIN DIRECTIONS IN THE EU MEMBER STATES RURAL DEVELOPMENT POLICIES: SIMILARITIES AND DISSIMILARITIES
}

\author{
Malgorzata Stanczuk-Galwiaczek ${ }^{1}$, M.Sc. Eng. \\ 1, Warsaw University of Technology, Faculty of Geodesy and Cartography
}

\begin{abstract}
The paper presents the comparison of key challenges addressed as the most significant to face within the rural development programmes 2014-2020 (RDP 2014-2020) in different Member States of the European Union. The paper aims to indicate main similarities and dissimilarities in the needs of the country's territories and priority targets of their rural development policies. The study presents the data on the amount of funding allocated to particular priority within the RDP 2014-2020 in each Member State. The study was based on the European Commission's data (factsheets on Rural Development Programmes 2014-2020 for each country).

The study results in the prioritization of distinguished challenges (priorities), where the level of importance to each challenge was assigned based on the amount of budget allocated to each priority. The research indicates that the issue of restoring, preserving and enhancing ecosystems in agriculture and forestry gains the greatest interest in the countries of European Union (the objective was given the highest priority rank in 24 out of 28 EU Member States), whereas the issue of resource efficiency and shift to low carbon and climate resilient economy in agriculture, food and forestry sectors (the priority coefficient assessed on the level of $7.4 \%$ ) and the issue of food chain organisation, animal welfare and risk management (the priority coefficient assessed on the level of $8.9 \%$ ) play the least significant role.
\end{abstract}

Key words: rural development, Rural Development Programme 2014-2020, EU rural development policy. JEL code: Q18

\section{Introduction}

Common Agricultural Policy (CAP) is one of the most important policies of the European Union (EU); it occupies the major share of the region's budget and has profound economic, social, political, environmental and cultural effects on agricultural development in the rural areas of EU Member States (Papadopoulos, 2015). Rural Development Programmes (RDPs) constitute the second pillar of the CAP. They are partly funded by the EU budget (the European Agricultural Fund for Rural Development - EAFRD) and partly co-financed by national and/or regional authorities. Current programming period 2014-2020 offers a total of 19 different RDP measures from which Member States/Regions may choose, designing sub-measures and operations suitable to their local needs.

European rural areas face several challenges. Over the last 60 years the unprecedented increase in food production has come at considerable cost to the natural environment and farmland biodiversity (Javadzadeh et al., 2014). Therefore, Europe places emphasis on programs that sponsor environmental services targeting at reducing negative externalities (e.g. nutrient run-off, soil erosion) and increasing positive externalities (e.g. preserving a farming heritage) and aims to support environmentally beneficial farming practices, including organic farming and the maintenance of existing low-intensity systems (Baylis et al., 2008; Ilbery and Bowler, 1998; Mullarkey et al., 2001; Pradziadowicz, 2017). Apart from environmental protection and preservation of biodiversity in rural areas, increasing attention should be drawn to climate change adaptation and resource efficiency (Ellen et al., 2011; Olesen and Bindi, 2002). Another crucial issue is promoting social inclusion and poverty reduction. According to EUROSTAT, (2017), rural citizens of EU are more at risk of poverty or social exclusion than urban inhabitants (25.5\% compared with $42.0 \%$ in the year 2015). What is more, attention should be diverted towards eliminating restraints on trade and distortions of competition in agricultural sector, unlocking local 
potential for economic diversification and going beyond agricultural restructuring (Gallent et al., 2015). Consideration should be given to the issue of promoting alternative food supply chains, as they can constitute a contribution to transitions concerning the shift from a productivist to a 'postproductivist' food regime and the public consumer pressure for a larger variety of distinctive 'quality' food products (Renting et al., 2003). Mentioned objectives need the open innovation type of approach (e.g. innovative farm technologies) and require knowledge transfer.

Accordingly, rural development programmes 2014-2020 for Member States or their regions should address at least four of the following challenges (six priorities):

- Priority 1 - Fostering knowledge transfer and innovation in agriculture, forestry and rural areas;

- Priority 2 - Enhancing the viability and competitiveness of all types of agriculture, and promoting innovative farm technologies and sustainable forest management;

- Priority 3 - Promoting food chain organisation, animal welfare and risk management in agriculture;

- Priority 4 - Restoring, preserving and enhancing ecosystems related to agriculture and forestry;

- Priority 5 - Promoting resource efficiency and supporting the shift toward a low-carbon and climate-resilient economy in the agriculture, food and forestry sectors;

- Priority 6 - Promoting social inclusion, poverty reduction and economic development in rural areas (European Commission, 2016).

Although the EU cohesion policy is aimed at the reduction of regional and social disparities in the EU territory (Hooghe, 1996), a strong level of rural areas' diversification within the EU Member States has to be outlined. There can be noticed differences and discrepancies between the countries or even their regions in relation to inter alia: (i) economic conditions such as the pace of economic development, agricultural labour input, agricultural prices, agricultural trade and farmers' incomes (Czyzewski and Kryszak, 2017; Kryszak and Staniszewski, 2017), (ii) level of living (Sompolska-Rzechula, 2017), (iii) rural population and social development (Vashchyk and Siudek, 2015; Siudek and Vashchyk, 2014), (iv) farm structure and land fragmentation (Van Dijk, 2003), (v) ecological development and environmental parametres and conditions (Kingston, 2011; Miklos and Spinerova, 2009), (vi) institutional mechanisms (Nowak et. al, 2016; Ramniceanu and Ackrill, 2007). According to Ciutacu C. et al. (2014), the conditions of agricultural production are varying widely especially between the East and the West of the continent, due to completely different policies and principles which have been followed after 1945 - Eastern agricultural production was structured on the principles of collective ownership, whereas the capitalist Western sector was based on the respect for private property and gaining profit with the backup of government intervention and unionist millitantism for progress (Ciutacu et al., 2008; Ciutacu et al., 2009). Taking all the discrepancies into account, the national policies should both implement the Common Agricultural Policy and be tailored to the most crucial needs and challenges of the particular territory of a country or a region, so that they uphold existing differences in Member States.

\section{Research object and methods}

The research aims to investigate main similarities and dissimilarities in the priority targets of EU Member States rural development policies. In order to achieve the research goal, the method of interstate comparative analyses was applied. The paper presents the comparison of key challenges addressed as the most significant to face within the rural development programmes 2014-2020 (RDP 2014-2020) in different Member States of the European Union. The research was 
based on the data on the amount of funding allocated to particular priority within the RDP 20142020 in each Member State. The data was obtained from the European Commission's factsheets on Rural Development Programmes 2014-2020 for each country (European Commission, 2017). In order to reach the aim, the author set following research tasks: (1) provision of summary statistics data on the public budget allocated to each distinguished challenge (priority P2, P3, P4, P5, P6) in 28 EU Member States within the RDPs 2014-2020, (2) prioritization of distinguished challenges, where the level of importance to each challenge was assigned based on the amount of budget allocated to each priority (elaboration of priority-ranked list of challenges in the agricultural policy of each Member State), (3) analysis of main disparities and similarities in funds allocation across Member States.

\section{Research results and discussion}

\section{Total public expenditure within the RDP 2014-2020 in each Member State}

According to the research results, the public funding allocated within the 118 Rural Development Programmes 2014-2020 adopted for different EU Member States equals to 156699 508196 EUR in total (author's calculations based on the European Commission's data included in the factsheets on public support allocated to each measure within the Rural Development Programmes 2014-2020 in each country). As share of total EU funding for RDP 2014-2020, the largest public budget allocations were noticed in Italy (12.0\%), Germany (10.8\%) and in France (10.5\%) (Figure 1).

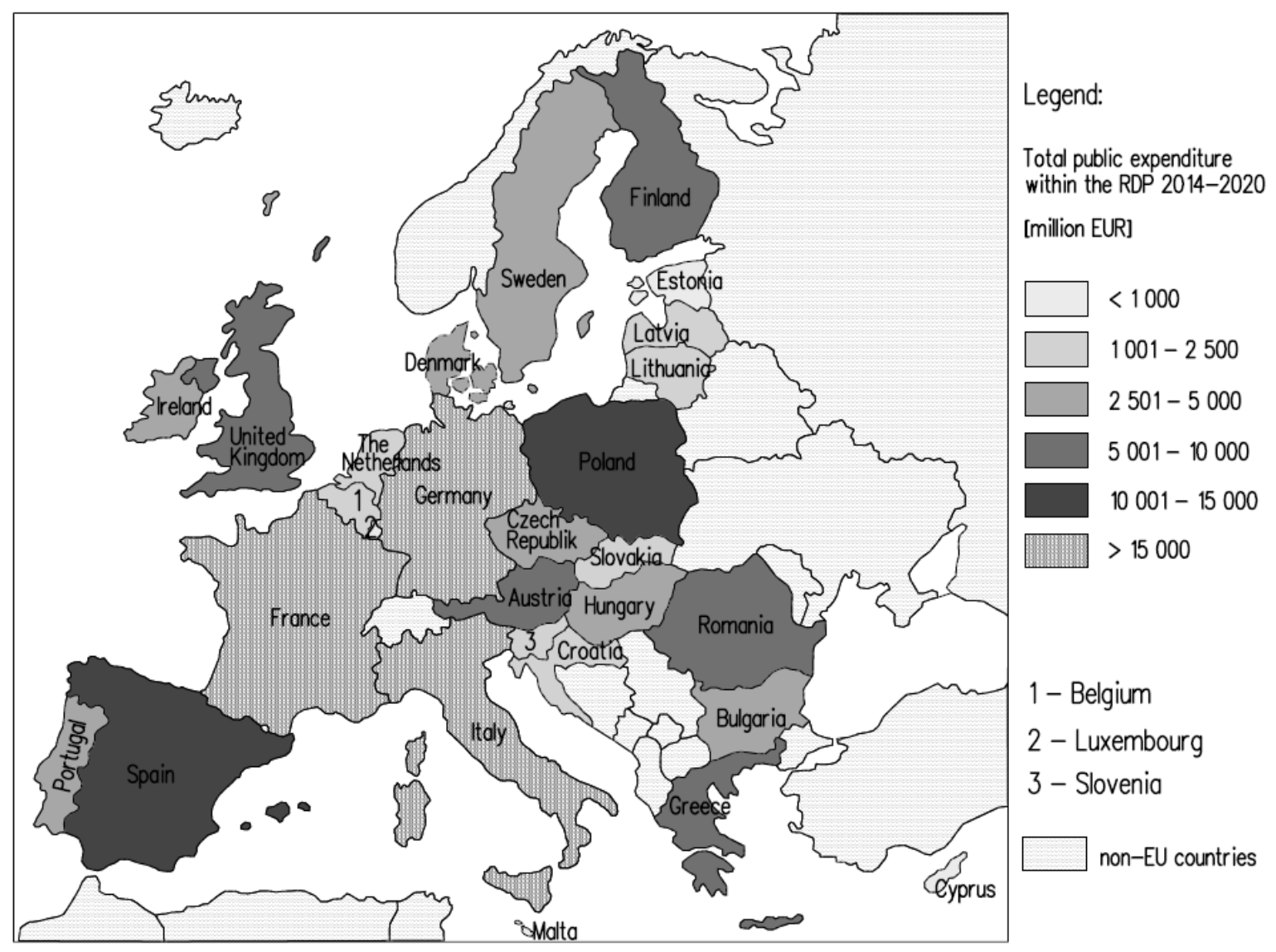

Source: author's study based on the European Commission's data

Fig. 1. Total public expenditure within the Rural Development Programmes for the years 20142020 in each European Union Member State 


\section{Share of funds per priority in the Rural Development Programmes 2014-2020}

The share of funds per priority (P2, P3, P4, P5) in the Rural Development Programmes for the years 2014-2020 in each EU Member State was investigated. The results of the study are presented in tabular form (Table 1). Some EU Member States adopted more than one RDP 20142020. In total, there were adopted 118 RDPs 2014-2020 in the EU. The study concerned the total amount of funds allocated to the whole country, without specification on the share of allocations in particular regions. No financial allocation for Priority 1 (P1) was shown in Table 1 in a separate column, as the expenditure is distributed across other five focus areas (P2, P3, P4, P5, P6). The table also does not include the data on public allocations dedicated to Technical Assistance and Discontinued Measure 113 (Transitional expenditure, Early retirement, etc.), which was taken into account in the research while investigating the total public expenditure within the RDP 2014-2020 for each country. Based on the obtained values the prioritization of challenges within the Rural Development Programmes 2014-2020 of each EU Member State was provided (See sub-part 3).

When analysing the share of funds per priority in the total public allocations for the Rural Development Programmes 2014-2020 in the EU (Figure 2), the largest amount of funding (45.3 \%) was allocated to the Priority 4 (Restoring, preserving and enhancing ecosystems related to agriculture and forestry), which is related to actions aimed at having agricultural land under contract to stimulate biodiversity, agricultural land to improve water management and agricultural land to improve soil management, as well as conversion or maintaining organic farming. This may suggest that rural policies of EU Member States exhibit strong consideration for the preservation of biodiversity in rural areas. Next, $21 \%$ of total public budget was designated to the Priority 2 (Enhancing the viability and competitiveness of all types of agriculture, and promoting innovative farm technologies and sustainable forest management), which is being followed by Priority 6 Promoting social inclusion, poverty reduction and economic development in rural areas $(15.0 \%)$. The lowest amount of funds was allocated to Priority 3 - Promoting food chain organisation, animal welfare and risk management in agriculture (8.9\%) and Priority 5 - Promoting resource efficiency and supporting the shift toward a low-carbon and climate-resilient economy in the agriculture, food and forestry sectors (7.4\%). For the last two mentioned priorities some Member States did not allocate funds at all (Denmark and Luxembourg in case of Priority 3; Slovenia and the Netherlands in case of Priority 5). Therefore, actions such as promoting alternative food supply chains, resource efficiency and climate adaptation are not treated as the highest-priority challenge in EU Member States' rural policies. 
Share of funds per priority (P2, P3, P4, P5) in the Rural Development Programmes for years 2014-2020 in each European Union Member State

\begin{tabular}{|c|c|c|c|c|c|}
\hline \multirow{2}{*}{ Country } & \multicolumn{5}{|c|}{ Allocated budget [EUR] per priority } \\
\hline & $\mathbf{P 2}$ & P3 & P4 & P5 & P6 \\
\hline Austria & 869370000 & 481887500 & 5156484523 & 244962352 & 827895625 \\
\hline Belgium & 560896517 & 40442949 & 578897258 & 240425830 & 135085602 \\
\hline Bulgaria & 371932203 & 272904039 & 983098024 & 430648778 & 815155429 \\
\hline Croatia & 711003205 & 278956380 & 650748724 & 200597894 & 468241752 \\
\hline Cyprus & 33950000 & 14850000 & 112100992 & 25299008 & 42500000 \\
\hline Czech Republic & 552103114 & 239979731 & 1976669627 & 24212095 & 231267428 \\
\hline Denmark & 140228816 & 0 & 768758131 & 134444926 & 77922074 \\
\hline Estonia & 283500000 & 105000000 & 365600000 & 23800000 & 176000000 \\
\hline Finland & 1024400000 & 559000000 & 5699531757 & 150400000 & 762000000 \\
\hline France & 3387284373 & 797183291 & 9090606419 & 1015282544 & 1874220813 \\
\hline Germany & 2699062381 & 1509926822 & 7510128854 & 740808469 & 4120138147 \\
\hline Greece & 860456151 & 406879731 & 2335082475 & 1161973779 & 676989595 \\
\hline Hungary & 715960741 & 771978936 & 1203443811 & 629185295 & 753193553 \\
\hline Ireland & 299800000 & 158300000 & 2842755630 & 456500000 & 250000000 \\
\hline Italy & 5234578218 & 2554287651 & 6865930185 & 1265567399 & 2434812362 \\
\hline Latvia & 510324909 & 93431601 & 574644817 & 75078545 & 236255704 \\
\hline Lithuania & 608644452 & 163519068 & 578117172 & 178900557 & 290789481 \\
\hline Luxembourg & 113400000 & 0 & 236023327 & 4000000 & 11141000 \\
\hline Malta & 17710263 & 15880919 & 52455545 & 25251941 & 13279762 \\
\hline Poland & 4474840477 & 1659610914 & 4160623209 & 300997069 & 2148939940 \\
\hline Portugal & 1720983734 & 119299782 & 1347896061 & 959589621 & 469054765 \\
\hline Romania & 1864161812 & 995367204 & 2813740122 & 1025842022 & 2563692738 \\
\hline Slovakia & 374294740 & 400390000 & 896538000 & 19223650 & 310093019 \\
\hline Slovenia & 223621867 & 101898083 & 575211499 & 0 & 167991552 \\
\hline Spain & 3209940623 & 1481416106 & 4547384189 & 1642091360 & 1575760246 \\
\hline Sweden & 358569218 & 189229285 & 2624336911 & 76803898 & 895284713 \\
\hline The Netherlands & 500750000 & 54000000 & 917770000 & 0 & 110480000 \\
\hline United Kingdom & 837286623 & 266347403 & 4747256500 & 375405321 & 802662767 \\
\hline TOTAL: & $32559 \mathrm{mln}$ & $13732 \mathrm{mln}$ & $70212 \mathrm{mln}$ & $11427 \mathrm{mln}$ & $23241 \mathrm{mln}$ \\
\hline
\end{tabular}




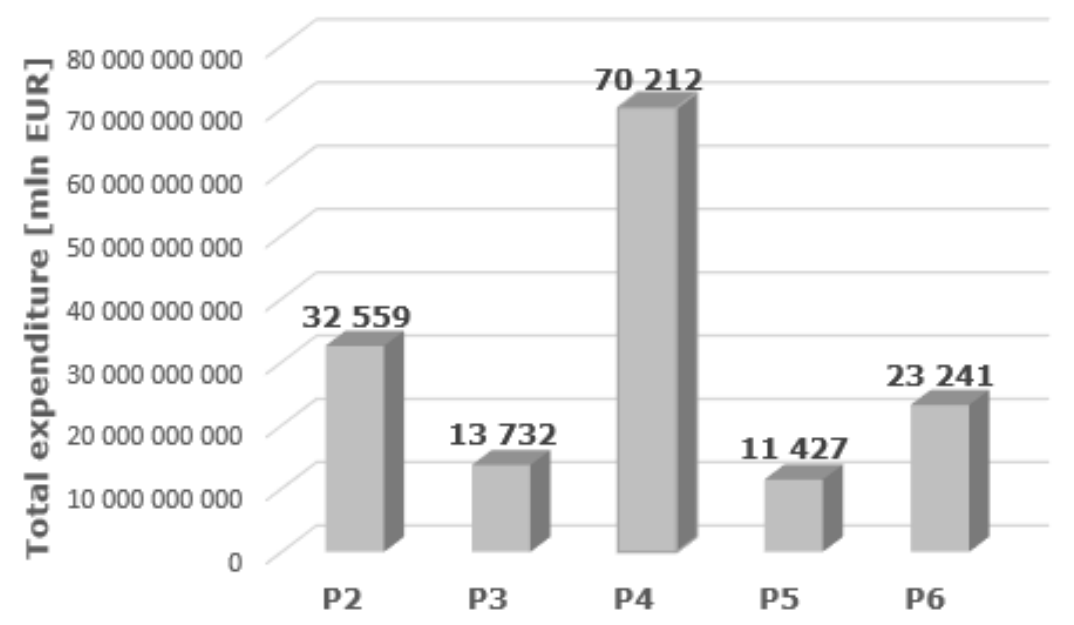

Source: author's calculations based on the European Commission's data

Fig. 2. Share of funds per priority (P2, P3, P4, P5) in the total public allocations for the Rural Development Programmes 2014-2020

\section{Prioritization of challenges within the Rural Development Programmes 2014- 2020}

For each EU Member State, the level of importance to each challenge was assigned basing on the priority coefficient $\left(H C_{P i}\right)$ calculated as the percentage share of budget allocated for particular priority (challenge) in the total public expenditure within the RDP 2014-2020:

$$
H c_{P i}=\frac{E_{P i}}{T E} \times 100 \%
$$

Where:

$H C_{P i}$ - priority coefficient for $i^{\text {th }}$ challenge $P_{i}$, where $i=2,3,4,5,6$;

$E_{P_{i}}$ - budget allocated for $i^{\text {th }}$ challenge (priority) $P_{i}$, where $i=2,3,4,5,6$;

$T E$ - total public expenditure within the RDP 2014-2020 (including public allocations dedicated to Technical Assistance and Discontinued Measure: transitional expenditure, early retirement).

The study results in the prioritization of distinguished challenges (P2, P3, P4, P5, P6) in each EU Member State (ranking), where the order of significance of each challenge was assigned based on the values of calculated priority coefficient $H c_{P i}$ (Table 2 ).

According to the study results, for the majority of EU Member States the distribution of funds per priority in RDPs is similar to the one for the whole European Union in terms of the priorities to which was allocated the largest and the lowest amount of money (Fig. 2). 24 out of 28 Member States allocated the largest amount of funding to Priority 4 (of which 8 countries allocated between $64 \%$ and $71 \%$ of total budget). The remaining 4 countries (Croatia, Lithuania, Poland, Portugal) allocated roughly the same amount of money (between $27 \%$ to $36 \%$ of total public expenditure) to both Priority 2 and 4 . Apart from Sweden and Ireland, none of the countries allocated less than $10 \%$ of total budget to challenge $\mathrm{P} 2$. 
The prioritization of challenges (P1, P2, P3, P4, P5)

within the rural development programmes 2014-2020 in each EU Member State

\begin{tabular}{|c|c|c|c|c|c|c|c|c|c|c|}
\hline \multirow[b]{2}{*}{ Country } & \multicolumn{2}{|c|}{ P2 } & \multicolumn{2}{|c|}{ P3 } & \multicolumn{2}{|c|}{ P4 } & \multicolumn{2}{|c|}{ P5 } & \multicolumn{2}{|c|}{ P6 } \\
\hline & $\begin{array}{c}\text { Ran } \\
\mathbf{k}^{*}\end{array}$ & $\begin{array}{l}\text { HcP2 } \\
{[\%]}\end{array}$ & $\begin{array}{c}\text { Rank } \\
*\end{array}$ & $\begin{array}{l}\text { HcP3 } \\
{[\% \text { \% }}\end{array}$ & $\begin{array}{c}\text { Rank } \\
*\end{array}$ & $\begin{array}{l}\text { HcP4 } \\
{[\% \text { \% }}\end{array}$ & $\begin{array}{c}\text { Rank } \\
*\end{array}$ & $\begin{array}{l}\text { HcP5 } \\
{[\%]}\end{array}$ & $\begin{array}{c}\text { Rank } \\
*\end{array}$ & $\begin{array}{l}\text { HcP6 } \\
{[\%]}\end{array}$ \\
\hline Austria & 2 & 11.1 & 4 & 6.2 & 1 & 66.0 & 5 & 3.1 & 3 & 10.6 \\
\hline Belgium & 2 & 35.5 & 5 & 2.6 & 1 & 36.7 & 3 & 15.2 & 4 & 8.6 \\
\hline Bulgaria & 4 & 12.7 & 5 & 9.4 & 1 & 33.7 & 3 & 14.8 & 2 & 27.9 \\
\hline Croatia & 1 & 29.8 & 4 & 11.7 & 2 & 27.3 & 5 & 8.4 & 3 & 19.6 \\
\hline Cyprus & 3 & 14.0 & 5 & 6.1 & 1 & 46.1 & 4 & 10.4 & 2 & 17.5 \\
\hline $\begin{array}{l}\text { Czech } \\
\text { Republic }\end{array}$ & 2 & 18.0 & 3 & 7.8 & 1 & 64.3 & 5 & 0.8 & 4 & 7.5 \\
\hline Denmark & 2 & 11.8 & 5 & 0.0 & 1 & 64.6 & 3 & 11.3 & 4 & 6.5 \\
\hline Estonia & 2 & 28.6 & 4 & 10.6 & 1 & 36.8 & 5 & 2.4 & 3 & 17.7 \\
\hline Finland & 2 & 12.4 & 4 & 6.8 & 1 & 69.0 & 5 & 1.8 & 3 & 9.2 \\
\hline France & 2 & 20.7 & 5 & 4.9 & 1 & 55.4 & 4 & 6.2 & 3 & 11.4 \\
\hline Germany & 3 & 16.0 & 4 & 8.9 & 1 & 44.4 & 5 & 4.4 & 2 & 24.4 \\
\hline Greece & 3 & 15.3 & 5 & 7.2 & 1 & 41.4 & 2 & 20.6 & 4 & 12.0 \\
\hline Hungary & 4 & 17.2 & 2 & 18.5 & 1 & 28.8 & 5 & 15.1 & 3 & 18.0 \\
\hline Ireland & 3 & 7.4 & 5 & 3.9 & 1 & 70.6 & 2 & 11.3 & 4 & 6.2 \\
\hline Italy & 2 & 27.9 & 3 & 13.6 & 1 & 36.6 & 5 & 6.8 & 4 & 13.0 \\
\hline Latvia & 2 & 32.4 & 4 & 5.9 & 1 & 36.4 & 5 & 4.8 & 3 & 15.0 \\
\hline Lithuania & 1 & 30.8 & 5 & 8.3 & 2 & 29.2 & 4 & 9.0 & 3 & 14.7 \\
\hline Luxembourg & 2 & 30.8 & 5 & 0.0 & 1 & 64.1 & 4 & 1.1 & 3 & 3.0 \\
\hline Malta & 3 & 13.6 & 4 & 12.2 & 1 & 40.4 & 2 & 19.5 & 5 & 10.2 \\
\hline Poland & 1 & 33.1 & 4 & 12.3 & 2 & 30.8 & 5 & 2.2 & 3 & 15.9 \\
\hline Portugal & 1 & 36.5 & 5 & 2.5 & 2 & 28.6 & 3 & 20.3 & 4 & 9.9 \\
\hline Romania & 3 & 19.7 & 5 & 10.5 & 1 & 29.7 & 4 & 10.8 & 2 & 27.1 \\
\hline Slovakia & 3 & 18.0 & 2 & 19.3 & 1 & 43.1 & 5 & 0.9 & 4 & 14.9 \\
\hline Slovenia & 2 & 20.2 & 4 & 9.2 & 1 & 51.9 & 5 & 0.0 & 3 & 15.2 \\
\hline Spain & 2 & 25.3 & 5 & 11.7 & 1 & 35.8 & 3 & 12.9 & 4 & 12.4 \\
\hline Sweden & 3 & 8.3 & 4 & 4.4 & 1 & 61.0 & 5 & 1.8 & 2 & 20.8 \\
\hline $\begin{array}{l}\text { The } \\
\text { Netherlands }\end{array}$ & 2 & 30.8 & 4 & 3.3 & 1 & 56.4 & 5 & 0.0 & 3 & 6.8 \\
\hline $\begin{array}{l}\text { United } \\
\text { Kingdom }\end{array}$ & 2 & 11.6 & 5 & 3.7 & 1 & 65.9 & 4 & 5.2 & 3 & 11.1 \\
\hline TOTAL: & 2 & 21.0 & 4 & 8.9 & 1 & 45.3 & 5 & 7.4 & 3 & 15.0 \\
\hline
\end{tabular}

In case of 16 countries, challenges P3 and P5 were located on two last places on the priority ranking list. The majority of the countries allocated to Priority 3 less than or equal to $12 \%$ of their total public budget. The rare exceptions were Hungary $(18.5 \%)$, Italy $(13.6 \%)$ and Slovakia $(19.3 \%)$. Regarding Priority 5, none of the countries allocated more than $15 \%$ of their total budget apart from Greece (20.6 \%), Malta (19.5\%) and Portugal (20.3\%). 13 countries allocated to priority P5 less than or equal to $5 \%$ of their total public allocations. This may suggest that those countries focus on different measures which can contribute to environmental and climate objectives 
(e.g. measures within priorities P2 and P4). However, measures possible to implement under priority P5 are crucial and should not be neglected. When analysing the budget reserved to priorities P4 and P5 in total, only 4 countries allocated less than $40 \%$ of their total budget: Poland (33.0 \%), Croatia (35.9\%), Lithuania (38.3\%) and Estonia (39.3\%). On the contrary, the largest public expenditure to P4 and P5 in total was noticed in Ireland (82\%), Denmark (76\%), Finland (71\%) and United Kingdom (71\%).

No clear distinction can be drawn between the distribution of funds in the 'old' and 'new' (the 13 countries which have joined the EU since 2004) Member States. However, 11 out of 13 'new' Member States allocated more than or equal to $15 \%$ of their total public budget to measures related to priority P6 (Social inclusion, poverty reduction, economic development), whereas the support allocated to P6 did not reach the level of $15 \%$ of total public budget among 'old' Member States (with exception of Germany (24\%) and Sweden (21\%)).

Based on the research calculations there can be distinguished some similar patterns of funds distribution in EU Member States (Table 3).

Table 3

\section{Distinguished patterns in the distribution of funds per priority (P2, P3, P4, P5) in the Rural Development Programmes for years 2014-2020 in EU Member State}

\begin{tabular}{|c|c|c|c|c|c|}
\hline \multirow{2}{*}{$\begin{array}{l}\text { Distinguished } \\
\text { Pattern }\end{array}$} & \multicolumn{5}{|c|}{ Share of funds per priority in the total public budget in EU Member States - HcPi } \\
\hline & $\mathbf{P 2}$ & P3 & P4 & P5 & P6 \\
\hline \multirow{2}{*}{$\begin{array}{l}\text { Pattern 1a } \\
\text { For countries: }\end{array}$} & $11-18 \%$ & $4-8 \%$ & $64-66 \%$ & $1-5 \% A$ & $8-11 \%$ \\
\hline & \multicolumn{5}{|c|}{ Austria, Czech Republic, Denmark, Finland, United Kingdom } \\
\hline \multirow{2}{*}{$\begin{array}{l}\text { Pattern 1b } \\
\text { For countries: }\end{array}$} & $31 \%$ & $0-3 \%$ & $56-64 \%$ & $0-1 \%$ & $3-7 \%$ \\
\hline & \multicolumn{5}{|c|}{ Luxembourg, The Netherlands } \\
\hline \multirow{2}{*}{$\begin{array}{l}\text { Pattern 2a } \\
\text { For countries: }\end{array}$} & $28-33 \%$ & $6-14 \%$ & $27-37 \%$ & $3-9 \%$ & $13-20 \%$ \\
\hline & \multicolumn{5}{|c|}{ Croatia, Estonia, Italy, Latvia, Lithuania, Poland } \\
\hline \multirow{2}{*}{$\begin{array}{l}\text { Pattern 2b } \\
\text { For countries: }\end{array}$} & $36 \%$ & $3 \%$ & $29-37 \%$ & $15-20 \%$ & $9-10 \%$ \\
\hline & \multicolumn{5}{|c|}{ Belgium, Portugal } \\
\hline \multirow{2}{*}{$\begin{array}{l}\text { Pattern } 3 a \\
\text { For countries: }\end{array}$} & $14-25 \%$ & $6-18 \%$ & $36-46 \%$ & $10-21 \%$ & $12-18 \%$ \\
\hline & \multicolumn{5}{|c|}{ Cyprus, Greece, Hungary, Spain } \\
\hline \multirow{2}{*}{$\begin{array}{l}\text { Pattern } 3 b \\
\text { For countries: }\end{array}$} & $13-20 \%$ & $9-12 \%$ & $30-44 \%$ & $11-19 \% B$ & $24-28 \% \mathrm{C}$ \\
\hline & \multicolumn{5}{|c|}{ Bulgaria, Germany, Malta, Romania } \\
\hline \multirow{2}{*}{$\begin{array}{l}\text { Pattern 3c } \\
\text { For countries: }\end{array}$} & $18-20 \%$ & $9-20 \%$ & $43-52 \%$ & $0-1 \%$ & $15 \%$ \\
\hline & \multicolumn{5}{|c|}{ Slovakia, Slovenia } \\
\hline \multicolumn{6}{|c|}{ Countries not fitting the distinguished patterns: France, Ireland, Sweden } \\
\hline \multicolumn{6}{|c|}{$\begin{array}{l}\text { Key: }{ }^{A} \text { ) Exception for Denmark } H_{C P S}=11.3 \% \\
B) \text { Exception for Germany } H c_{P S}=4.4 \% \\
\text { C) Exception for Malta } H_{P S}=10.2 \% \\
\text { The highest-priority challenge }\left(P_{i}\right) \text { in each pattern underlined. } \\
\text { Source: author's study based on the European Commission's data }\end{array}$} \\
\hline
\end{tabular}

\section{Conclusions, proposals, recommendations}

1) Despite the strong level of diversification in the rural areas in EU Member States, there can be noticed some similarities in the hierarchy of the priorities adopted in the RDPs 2014-2020. The majority of Member States (24 out of 28 countries) allocated the largest amount of funding to Priority 4, which may suggest that EU countries pay a great deal of attention to the issues of preservation of ecosystems and biodiversity in rural areas. Challenge P4 was in most cases 
being followed by P2 (actions related to enhancing farm viability competitiveness and sustainable forest management) in the priority ranking list.

2) There can be distinguished some similar patterns of funds distribution in EU Member States (countries not fitting the distinguished patterns are France, Ireland, Sweden). The RDPs for each country focus mainly on one or two priorities: P2, P2 and P4 or P4 and P6 (more than $25 \%$ of total budget allocated per priority).

3) Actions related to promoting alternative food supply chains, resource efficiency and climate adaptation are not treated as the highest-priority challenge in the RDPs of the majority of the EU Member States (challenges P3 and P5 were ranked as priorities of the lowest significance in general). In case of 16 countries, challenges P3 and P5 were located on two last places on the priority ranking list. Denmark and Luxembourg did not allocate funds at all in case of Priority 3 and Slovenia and the Netherlands in case of Priority 5. High significance assigned to Priority 3 can be noticed only in a few Member States (Hungary, Italy, Slovakia). Regarding Priority 5, none of the countries allocated more than $15 \%$ of their total budget apart from Greece, Malta and Portugal.

4) 13 countries allocated less than or equal to $5 \%$ of their total public expenditure to priority P5 (Resource-efficient, Climate-resilient Economy). However, when analysing the budget reserved to priorities P4 and P5 in total, only 4 countries allocated less than $40 \%$ of their total budget: Poland $(33.0 \%)$, Croatia (35.7\%), Lithuania (38.3\%) and Estonia (39.3\%). The author's research leads to the conclusion that it is very important to conduct information and education campaigns on agri-environmental issues in the mentioned countries. In the upcoming programming period, a further attempt to address the environmental, climate adaptation and resource efficiency issues in the RDPs should be made and a larger amount of funding should be allocated to these objectives.

5) No clear distinction can be drawn between the distribution of fund in the 'old' and 'new' Member States. However, most of the 'new' Member States tend to allocate more funding to Priority 6 (Social inclusion, poverty reduction, economic development) than the 'old' Member States.

\section{Bibliography}

1. Baylis, K., Peplow, S., Rausser, G., Simon, L., (2008). Agri-environmental Policies in the EU and United States: A comparison. Ecological Economics 65 (2008), pp. 753-764.

2. Ciutacu, C., Chivu, L., Andrei, J.V., (2014). Similarities and Dissimilarities between the EU Agricultural and Rural Development Model and Romanian Agriculture. Challenges and perspectives. Land Use Policy 44 (2015), pp. 169-176.

3. Ciutacu, C., Chivu, L., Mark, C., (2008). E'tude comparative dans le secteur del'agriculture de L'union Européenne. Rom. J. Econ. 27/2 (36), pp. 40-56.

4. Ciutacu, C., Chivu, L., Raluca, I.I., (2009). The Global Financial Crisis: Management of Deficits and Debts. Amfiteatru Econ. J. 11 (Number Special 3), pp. 735-750.

5. Czyzewski, A., Kryszak, L., (2017). Agricultural Income and Process. The Interdependence of Selected Phenomena in Poland Compared to EU-15 Member States. Managerial Economics 2017, vol. 18, no. 1 , pp. 47-62

6. Ellen, G.J., Hommes, S., Kalweit, A.M., Lamoen, F.v., Melisie, E.J., Maring, L., Paalman, M., Peerdeman, K., Rooij, S.A.M.v., Steingrover, E.G., (2011). Multifunctioneel landgebruik als adaptatiestrategie: puzzelen met ondernemers en beleidsmakers. Kennis voor Klimaat rapport KvK/036/2011. Kennis voor Klimaat, Utrecht, the Netherlands, $89 \mathrm{pp}$.

7. European Commission, (2017). Rural Development 2014-2020: Country Files. Retrieved: https://ec.europa.eu/agriculture/rural-development-2014-2020/country-files_en. Access: 29.01.2018.

8. European Commission, (2016). Rural Development 2014-2020. Retrieved: https://ec.europa.eu/agriculture/rural-development-2014-2020_en. Access: 02.02.2018. 
9. EUROSTAT, (2017). Europe 2020 Indicators - Poverty and Social Exclusion. Retrieved: http://ec.europa.eu/eurostat/statistics-explained/index.php/Europe_2020_indicators__poverty_and_social_exclusion. Access: 02.02.2018.

10. Gallent, N., Hamiduddin, I., Juntti, M., Kidd, S., Shaw, D., (2015). Introduction to Rural Planning. Economies, Communities and Landscapes. $2^{\text {nd }}$ Edition. The Natural and Built Environment Series. Routledge, Taylor and Francis Group, New York and London, 366 pp.

11. Hooghe, L., (1996). Introduction: Reconciling EU-Wide Policy and National Diversity. In: L. Hooghe (Ed.), Cohesion Policy and European Integration: Building Multi-Level Governance. Oxford University Press Inc., New York, pp. 1-26.

12. Ilbery, B., Bowler, I., (1998). From Agricultural Productivism to Post-productivism. In: B. Ilbery (Ed.), The Geography of Rural Change. Longman, London, pp. 57-84.

13. Javadzadeh, S.M., Mehraban, A., Ebrahimi, A., Javadi, H. (2014). Agri-Environmental: A Review. Adv. Agric. Biol. 2 (2), 2014, pp. 93-104.

14. Kingston, S. (2011). Greening EU Competition Law and Policy. Cambridge University Press, Cambridge, $474 \mathrm{pp}$.

15. Kryszak, L., Staniszewski, J., (2017). The Elasticity of Agricultural Income in the EU Member States under Different Cost Structures. Scientific Journal Warsaw University of Life Sciences - SGGW Problems of World Agriculture volume 17 (XXXII), number 4, 2017, pp. 182-192.

16. Miklos, L., Spinerova, A., (2009). The Environmental Conditions in Carpathian Basin and the Environmental Policy of European Union. Acta Universitatis Sapientiae Agriculture and Environment 1 (2009), pp. 83-92.

17. Mullarkey, D., Cooper, J., Skully, D., (2001). Multifunctionality of Agriculture: Do Mixed Goals Distort Trade. Choices, First Quarter 2001, pp. 31-34.

18. Nowak, A., Janulewicz, P., Krukowski, A., Bujanowicz-Haras, B., (2016). Diversification of the Level of Agricultural Development in the Member States of the European Union. Cah. Agric. 2016, 25: 55004, pp. 17.

19. Olesen, J.E., Bindi, M., (2002). Consequences of Climate Change for European Agricultural Productivity, Land Use and Policy. European Journal of Agronomy 16, pp. 239-262.

20. Papadopoulos, A.G., (2015). The Impact of the CAP on Agriculture and Rural Areas of EU Member States. Agrarian South: Journal of Political Economy: A tri-annual Journal of CARES Vol. 4 (1), pp. 22-53.

21. Pradziadowicz, M., (2017). Realization of Agri-environmental Program in Western Pomerania in the Years 2007-2013. Proceedings of the 2017 International Conference "ECONOMIC SCIENCE FOR RURAL DEVELOPMENT" No 44, Jelgava, LLU ESAF, 27-28 April 2017, pp. 161-165

22. Ramniceanu, I., Ackrill, R., (2007). EU Rural Development Policy in the New Member States: Promoting Multifunctionality? Journal of Rural Studies Vol. 23 (4), pp. 416-429.

23. Renting, H., Marsden, T., Banks, J., (2003). Understanding Alternative Food Networks: Exploring the Role of Short Food Supply Chains in Rural Development. Environment and Planning Vol. 35 (2003), pp. 393-411.

24. Siudek, T., Vashchyk, M., (2014). Economic Development of Rural Areas in European Union Member States in 2000-2012. Oeconomia 13 (3) 2014, pp. 95-104.

25. Sompolska-Rzechula, A. (2017). Diversification of Rural Areas in Poland in Terms of Level of Living. Proceedings of the 2017 International Conference "ECONOMIC SCIENCE FOR RURAL DEVELOPMENT" No 44, Jelgava, LLU ESAF, 27-28 April 2017, pp. 182-189

26. Van Dijk, T., (2003). Scenarios of Central European Land Fragmentation. Land Use Policy 20 (2), pp. 149158.

27. Vashchyk, M., Siudek, T. (2015). Social Development of Rural Areas in the European Union Member States in 2000-2012. Roczniki Naukowe Ekonomii Rolnictwa i Rozwoju Obszarow Wiejskich, T. 102, z. 1, 2015, pp. 7-17. 